\title{
Severe right ventricular hypertrophy in hypertrophic cardiomyopathy: Serious symptoms, complex surgical procedures, and poor prognosis in Fuwai Hospital
}

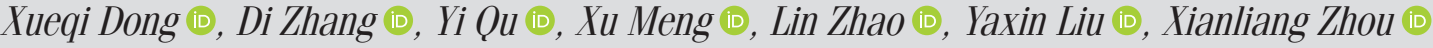 \\ Department of Cardiology, Fuwai Hospital, National Center for Cardiovascular Disease, \\ Chinese Academy of Medical Sciences and Peking Union Medical College; Beijing-China
}

\section{ABSTRACT}

Objective: Severe right ventricular hypertrophy (SRVH) in hypertrophic cardiomyopathy (HCM) is rare. We studied the clinical characteristics and prognosis of 36 patients with HCM and SRVH in a Chinese cohort.

Methods: Patients with HCM and SRVH were enrolled between 2013 and 2017. The clinical characteristics, treatment therapies, and clinical outcomes of the 36 patients were retrospectively studied and compared with those of 128 patients without SRVH.

Results: Patients in the group with SRVH were younger than those in the group without SRVH $(27.58 \pm 15.09$ years vs $40.34 \pm 13.21$ years, respectively; $\mathrm{p}<0.001)$. Patients with SRVH had more serious clinical symptoms and a higher New York Heart Association functional class than those without SRVH. Most patients in the group with SRVH exhibited diffuse RV hypertrophy, and 13 patients presented with biventricular outflow tract obstruction. Maximal left ventricular (LV) wall thickness $(27.29 \pm 7.95 \mathrm{~mm}$ vs $24.33 \pm 5.85 \mathrm{~mm}$, respectively; $\mathrm{p}=0.027)$ and LV outflow tract gradient $(80.83 \pm 24.41 \mathrm{~mm} \mathrm{Hg}$ vs $42.3 \pm 5.7 \mathrm{~mm} \mathrm{Hg}$, respectively; $\mathrm{p}=0.000$ ) were significantly greater in patients with SRVH than in those without SRVH. A total of 30 patients in the group with SRVH underwent surgical correction. During a median follow-up period of 48 months, six patients with SRVH reached primary clinical endpoints (four sudden cardiac deaths, one heart failure-related death, and one heart transplantation), whereas only two deaths occurred in the patients without SRVH.

Conclusion: We conclude that patients with HCM and SRVH exhibit serious symptoms and have complex surgical requirements and poor clinical outcomes.

Keywords: hypertrophic cardiomyopathy, right ventricular, ventricular outflow obstruction, sudden cardiac death

Cite this article as: Dong $X$, Zhang D, Qu Y, Meng X, Zhao L, Liu Y, et al. Severe right ventricular hypertrophy in hypertrophic cardiomyopathy: Serious symptoms, complex surgical procedures, and poor prognosis in Fuwai Hospital. Anatol J Cardiol 2021; 25: 476-83.

\section{Introduction}

Hypertrophic cardiomyopathy ( $\mathrm{HCM}$ ) is the most common inherited structural heart disease. It is one of the leading causes of sudden cardiac death (SCD) in young individuals and can lead to heart failure symptoms or death at any age $(1,2)$. Although the European Society of Cardiology definition of HCM (3) is based on left ventricular (LV) wall thickness ( $\geq 15 \mathrm{~mm}$ in one or more myocardial segments that is not explained solely by loading conditions), right ventricular (RV) involvement in HCM is not uncom- mon (4). In previous studies, cardiac magnetic resonance (CMR) imaging and echocardiography identified RV hypertrophy in $30 \%-53 \%$ of patients with $\mathrm{HCM}(5,6)$. Mild to moderate RV hypertrophy in conjunction with LV hypertrophy is commonly observed; however, severe RV hypertrophy (SRVH) with a maximal RV wall thickness $\geq 10 \mathrm{~mm}$, even with biventricular systolic obstruction, is relatively infrequent. Limited data are available regarding the impact of SRVH on adverse clinical outcomes. In this study, we investigated the clinical features, treatment options, and clinical outcomes of patients with HCM and SRVH.

Address for Correspondence: Xianliang Zhou, MD, Department of Cardiology, Fuwai Hospital, National Center for Cardiovascular Disease, Chinese Academy of Medical Sciences and

Peking Union Medical College, No. 167, Beilishi Road, 100037, Beijing-China

E-mail: zhouxianliang0326@hotmail.com

Accepted Date: 18.01.2021 Available Online Date: 03.06.2021

(C) Copyright 2021 by Turkish Society of Cardiology - Available online at www.anatoljcardiol.com DOI:10.5152/AnatolJCardiol.2021.98537 


\section{HIGHLIGHTS}

- Incidence of severe right ventricular hypertrophy (SRVH) in patients with hypertrophic cardiomyopathy (HCM) was relatively uncommon.

- $\quad$ SRVH was correlated with more severe obstructive HCM phenotypes.

- Biventricular resection was the main surgical method performed in patients with biventricular outflow tract obstruction, showing a clear improvement in clinical symptoms.

- Patients with SRVH face a high risk of sudden cardiac death even after successful surgery.

\section{Methods}

\section{Patients}

Among approximately 5,000 patients who underwent CMR imaging in our hospital from January 2013 to December 2017, 1,316 patients with HCM were identified by searching for the terms hypertrophic cardiomyopathy or hypertrophic obstructive cardiomyopathy in the imaging reports. Of these 1,316 patients with HCM, $36(2.74 \%)$ had SRVH. From the remaining 1,280 (97.26\%) patients without SRVH, we randomly selected 128 patients according to their case numbers. Thus, we enrolled a total of 164 patients in this study and retrospectively analyzed their clinical characteristics, family history, echocardiography results, and CMR imaging results using an electronic medical records system. Figure 1 shows the process of patient recruitment.

The study complied with the Declaration of Helsinki (World Medical Assembly) and its amendments and was approved by the Ethics Committee of our institution. Informed consent was not required because of the retrospective nature of the study.

\section{Definitions}

The diagnosis of HCM was based on two-dimensional echocardiographic and/or CMR imaging documentation of a maximum LV wall thickness $\geq 15 \mathrm{~mm}$ in the absence of any other cause capable of producing a similar degree of hypertrophy or the presence of a maximum LV wall thickness $\geq 13 \mathrm{~mm}$ and a family history of HCM. SRVH was defined as an end-diastolic RV anterior, free, or apical wall thickness $\geq 10 \mathrm{~mm}$ on the basis of CMR imaging (7). LV outflow tract obstruction (LVOTO) was defined as a LV outflow tract pressure gradient $>30 \mathrm{~mm} \mathrm{Hg}$ under resting conditions (8). RV outflow tract obstruction (RVOTO) was defined as an RV outflow tract pressure gradient $>25 \mathrm{~mm} \mathrm{Hg}$ under resting conditions (9). Biventricular outflow tract obstruction (BVOTO) was defined as the simultaneous presence of LVOTO and RVOTO.

\section{Follow-up}

Prospective clinical follow-up was conducted on both groups of patients. Data regarding patient survival and the clinical status

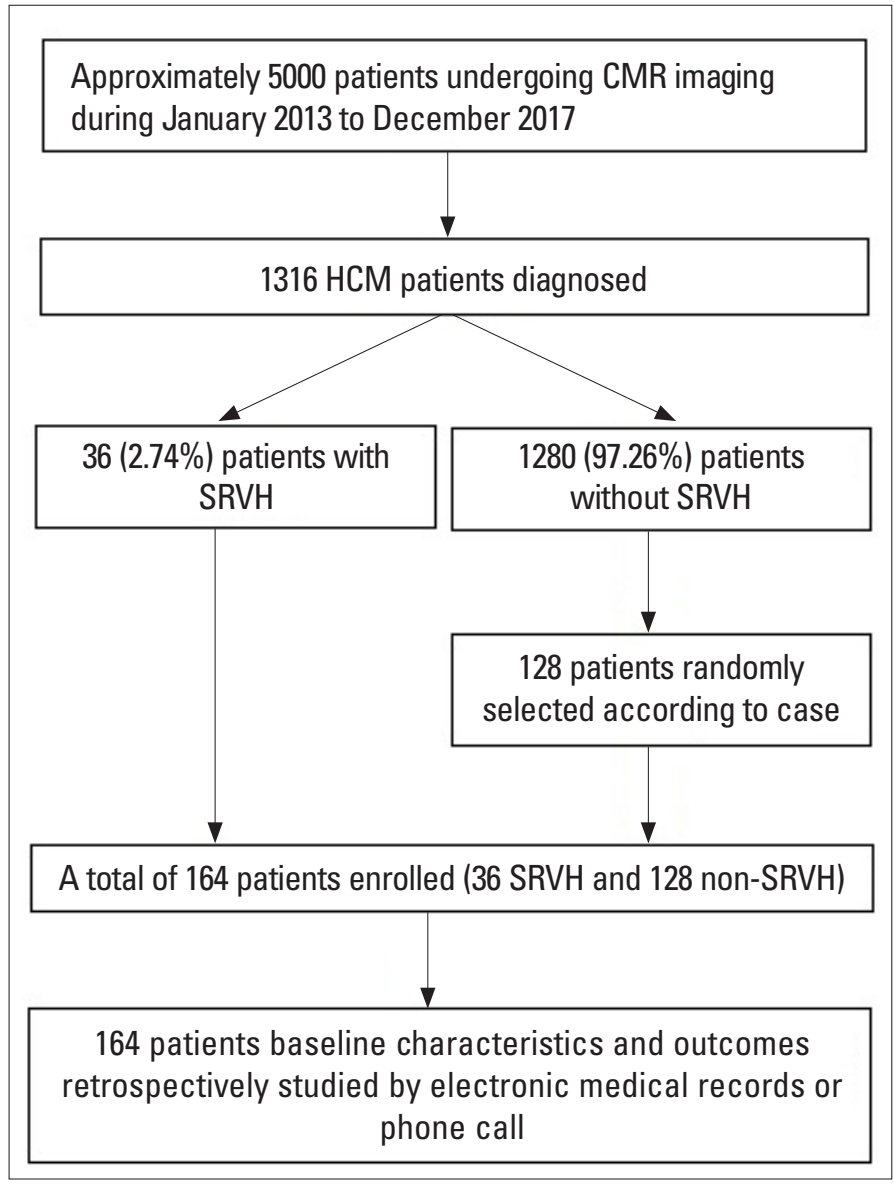

Figure 1. Scheme of patient recruitment

were obtained from either the medical records or detailed interviews. The primary clinical endpoints were SCD, heart transplantation, heart failure-related death, stroke-related death, aborted cardiac arrest, and appropriate discharge of an implantable cardioverter-defibrillator for ventricular fibrillation (10).

\section{Statistical analysis}

Statistical analysis was performed using Statistical Package for the Social Sciences, version 22.0 (IBM Corp., Armonk, NY, USA). Descriptive data are presented as mean \pm standard deviation, and nominal variables are presented as frequency. Data were tested for a normal distribution using the Kolmogorov-Smirnov test. Variables were compared using Student's t-test, and paired continuous data were analyzed by paired-sample t-test. The chi-square test or Fisher's exact test (when the expected value was $<5$ ) was used to compare nominally scaled variables. Survival estimates were calculated using the Kaplan-Meier method and the log-rank test. The annual event rate was calculated as the number of adverse clinical events divided by the average follow-up period in years. For all tests, a $p$-value $<0.05$ was considered statistically significant.

\section{Results}

\section{Baseline clinical characteristics}

From January 1, 2013 to December 31, 2017, 36 patients with 


\begin{tabular}{|c|c|c|c|}
\hline Clinical characters & SRVH $(n=36)$ & $\begin{array}{c}\text { No SRVH } \\
(\mathrm{n}=128)\end{array}$ & $\boldsymbol{P}$ \\
\hline Gender (male) & $23(63.9 \%)$ & $86(67.2 \%)$ & 0.711 \\
\hline Diagnostic age (years) & $27.58 \pm 15.09$ & $40.34 \pm 13.21$ & $<0.001$ \\
\hline HCM family history & $8(22.2 \%)$ & $25(19.5 \%)$ & 0.722 \\
\hline SCD family history & $6(16.7 \%)$ & $20(15.6 \%)$ & 0.909 \\
\hline \multicolumn{4}{|l|}{ Symptoms } \\
\hline Dyspnea & $17(47.2 \%)$ & $45(35.2 \%)$ & 0.534 \\
\hline Chest pain & $27(75 \%)$ & $88(68.75 \%)$ & 0.897 \\
\hline Palpitation & $14(38.9 \%)$ & $55(42.96 \%)$ & 0.764 \\
\hline Syncope & $7(19.44 \%)$ & $29(22.66 \%)$ & 0.476 \\
\hline$>3$ symptoms & $16(44.4 \%)$ & $37(28.91 \%)$ & $<0.001$ \\
\hline Arrythmias & $8(22.2 \%)$ & $11(8.6 \%)$ & 0.017 \\
\hline Atrial fibrillation & $4(11.1 \%)$ & $6(4.7 \%)$ & \\
\hline Ventricular tachycardia & $4(11.1 \%)$ & $5(3.90 \%))$ & \\
\hline \multicolumn{4}{|l|}{ NYHA class } \\
\hline 1 & $0(0 \%)$ & $61(47.7 \%)$ & \\
\hline II & $12(33.3 \%)$ & $52(40.6 \%)$ & \\
\hline III & $22(61.1 \%)$ & $10(7.8 \%)$ & \\
\hline IV & $2(5.6 \%)$ & $5(3.9 \%)$ & $<0.001$ \\
\hline Hypertension & $4(11.1 \%)$ & $42(32.8 \%)$ & 0.432 \\
\hline Coronary heart disease & $3(8.3 \%)$ & $14(10.9 \%)$ & 0.767 \\
\hline Coronary muscle bridge & $2(5.55 \%)$ & $10(7.81 \%)$ & 0.423 \\
\hline Valvular heart disease & $5(13.89 \%)$ & $14(10.9 \%)$ & 0.746 \\
\hline Congenital heart disease & $3(8.33 \%)$ & $3(2.3 \%)$ & 0.044 \\
\hline \multicolumn{4}{|l|}{ Treatment } \\
\hline Medicine & $4(11.11 \%)$ & $116(90.63 \%)$ & \\
\hline Surgery & $30(83.33 \%)$ & $12(9.4 \%)$ & \\
\hline Heart transplantation & $1(2.77 \%)$ & 0 & \\
\hline Alcohol ablation & $1(2.77 \%)$ & 0 & \\
\hline ICD & 0 & $1(0.8 \%)$ & $<0.001$ \\
\hline \multicolumn{4}{|c|}{$\begin{array}{l}\text { Data are presented as } n(\%) \text { or mean } \pm \text { standard deviation. } \\
\text { HCM - hypertrophic cardiomyopathy; ICD - implantable cardioverter-defibrillator; NYHA - } \\
\text { New York Heart Association; SCD - sudden cardiac death; SRVH - severe right ventricular } \\
\text { hypertrophy }\end{array}$} \\
\hline
\end{tabular}

SRVH and 128 patients without SRVH were enrolled in this study. Patients in the group with SRVH were younger than those in the group without SRVH (age of $27.58 \pm 15.09$ vs $40.34 \pm 13.21$ years, respectively; $p<0.001$ ). There were no significant differences in sex, family history of HCM, or family history of SCD between the two groups. The group with SRVH tended to have more serious clinical symptoms, such as dyspnea, chest pain, palpitations, and syncope, than the group without SRVH. A total of 16 patients $(44.5 \%)$ in the group with SRVH had more than three symptoms, whereas only 37 patients $(28.9 \%)$ in the group without SRVH had

\begin{tabular}{|c|c|c|c|}
\hline Imaging data & SRVH $(n=36)$ & $\begin{array}{c}\text { No SRVH } \\
(n=128)\end{array}$ & $P$ \\
\hline \multicolumn{4}{|l|}{ Echo parameters } \\
\hline $\mathrm{LA}(\mathrm{mm})$ & $42.12 \pm 7.31$ & $41.71 \pm 8.13$ & 0.883 \\
\hline LVPWT (mm) & $13.42 \pm 4.64$ & $12.97 \pm 4.11$ & 0.590 \\
\hline LVEDD (mm) & $40.45 \pm 8.646$ & $42.52 \pm 5.73$ & 0.096 \\
\hline $\operatorname{LVEF}(\%)$ & $68.14 \pm 12.81$ & $69.95 \pm 8.52$ & 0.344 \\
\hline IVS (mm) & $27.29 \pm 7.95$ & $24.33 \pm 5.85$ & 0.027 \\
\hline Increased RA (\%) & $2(5.6 \%)$ & $6(4.7 \%)$ & 0.041 \\
\hline LVOT gradient (mm Hg) & $80.83 \pm 24.41$ & $42.3 \pm 5.7$ & $<0.001$ \\
\hline $\begin{array}{l}\text { RVOT gradient }(\mathrm{mm} \mathrm{Hg}) \\
(\mathrm{n}=13)\end{array}$ & $44.86 \pm 25.5$ & NA & $<0.001$ \\
\hline \multicolumn{4}{|l|}{ MRI parameters } \\
\hline $\mathrm{LA}(\mathrm{mm})$ & $43.07 \pm 11.77$ & $42.17 \pm 7.67$ & 0.755 \\
\hline LVWT (mm) & $14.01 \pm 4.87$ & $13.35 \pm 5.01$ & 0.654 \\
\hline LVEDD (mm) & $43.76 \pm 5.96$ & $44.65 \pm 7.32$ & 0.120 \\
\hline $\operatorname{LVEF}(\%)$ & $66.90 \pm 13.49$ & $67.76 \pm 7.54$ & 0.456 \\
\hline CO & $5.83 \pm 2.01$ & $5.96 \pm 2.56$ & 0.432 \\
\hline IVS (mm) & $29.67 \pm 7.97$ & $26.68 \pm 6.02$ & 0.018 \\
\hline RVWT (mm) & $10.4 \pm 2.9$ & $<10$ & $<0.001$ \\
\hline Biventricular obstruction & 13 & NA & $<0.001$ \\
\hline LGE & $35(97.2 \%)$ & $70(54.68 \%)$ & 0.013 \\
\hline \multicolumn{4}{|c|}{$\begin{array}{l}\text { Data are presented as n (\%) or mean } \pm \text { standard deviation. } \\
\text { CO - cardiac output; Echo - echocardiographic; IVS - interventricular septum; LA - left } \\
\text { atrium; LGE - late gadolinium enhancement; LVEDD - left ventricular end-diastolic } \\
\text { dimension; LVEF - left ventricular ejection fraction; LVOT - left ventricular outflow tract; } \\
\text { LVPWT - left ventricular posterior wall thickness; LVWT - left ventricular wall thickness; } \\
\text { MRI - magnetic resonance imaging; NA - not available; RA - right atrium; RVOT - right } \\
\text { ventricular outflow tract; RVWT - right ventricular wall thickness; SRVH - severe right } \\
\text { ventricular hypertrophy }\end{array}$} \\
\hline
\end{tabular}

more than three symptoms $(p<0.001)$. In addition, patients with SRVH had worse functional capacity than those without SRVH [New York Heart Association (NYHA) functional class III/IV: $n=24$ $(66.7 \%)$ vs. $\mathrm{n}=15(11.7 \%)$, respectively; $\mathrm{p}<0.001]$. Moreover, patients in the group with SRVH had a higher incidence of arrhythmia than those in the group without SRVH. The prevalence of atrial fibrillation and nonsustained ventricular tachycardia in the group with SRVH and the group without SRVH was $22.2 \%$ and $8.6 \%$, respectively $(p<0.001)$. The baseline clinical characteristics in the groups with and without SRVH are summarized in Table 1.

\section{Echocardiography and CMR imaging features in patients with SRVH}

All the 164 patients included in this study underwent at least one echocardiographic examination and at least one late gadolinium enhancement (LGE) CMR imaging examination. The echocardiographic and CMR imaging parameters in the groups with and without SRVH at baseline are shown in Table 2. 


\begin{tabular}{|c|c|c|c|c|c|c|c|c|c|c|c|}
\hline$\#$ & $\begin{array}{l}\text { Age } \\
\text { gender }\end{array}$ & Symptoms & $\begin{array}{l}\text { NYHA } \\
\text { class }\end{array}$ & $\begin{array}{l}\text { Onset of } \\
\text { symptoms }\end{array}$ & $\begin{array}{l}\text { Family } \\
\text { history of } \\
\text { HCM/SCD }\end{array}$ & $\begin{array}{l}\text { LV } \\
\text { patterns of } \\
\text { obstruction }\end{array}$ & $\begin{array}{l}\text { LV } \\
\text { myectomy }\end{array}$ & $\begin{array}{l}\text { RV } \\
\text { patterns of } \\
\text { obstruction }\end{array}$ & RV surgery & $\begin{array}{l}\text { Additional } \\
\text { procedures }\end{array}$ & Outcomes \\
\hline 1 & $\begin{array}{l}22 \\
\text { female }\end{array}$ & $\begin{array}{l}\text { Chest pain } \\
\text { dyspnea }\end{array}$ & 2 & 15 & No/No & $\begin{array}{l}\text { Subaortic } \\
\text { APM }\end{array}$ & $\begin{array}{l}\text { TAortic } \\
\text { APM } \\
\text { resection }\end{array}$ & $\begin{array}{l}\text { Septal } \\
\text { Free wall }\end{array}$ & $\begin{array}{l}\text { Septal } \\
\text { resection Free } \\
\text { wall resection }\end{array}$ & & NYHA 1 \\
\hline 2 & $\begin{array}{l}20 \\
\text { male }\end{array}$ & Chest pain & 3 & 14 & No/No & $\begin{array}{l}\text { Subaortic } \\
\text { APM }\end{array}$ & $\begin{array}{l}\text { TAortic } \\
\text { APM } \\
\text { resection }\end{array}$ & $\begin{array}{l}\text { Septal } \\
\text { Free wall } \\
\text { Infundibular }\end{array}$ & $\begin{array}{l}\text { Septal } \\
\text { resection Free } \\
\text { wall resection } \\
\text { Infundibular } \\
\text { resection } \\
\text { RVOT patch }\end{array}$ & CABG & NYHA 2 \\
\hline 3 & $\begin{array}{l}14 \\
\text { male }\end{array}$ & $\begin{array}{l}\text { Chest pain } \\
\text { dyspnea } \\
\text { syncope }\end{array}$ & 3 & 13 & No/No & $\begin{array}{l}\text { Subaortic } \\
\text { APM }\end{array}$ & $\begin{array}{l}\text { TAortic } \\
\text { APM } \\
\text { resection }\end{array}$ & $\begin{array}{l}\text { Septal } \\
\text { Free wall } \\
\text { Infundibular }\end{array}$ & $\begin{array}{l}\text { Septal } \\
\text { resection Free } \\
\text { wall resection } \\
\text { Infundibular } \\
\text { resection }\end{array}$ & & $\begin{array}{l}\text { SCD after } \\
\text { three } \\
\text { years }\end{array}$ \\
\hline 4 & $\begin{array}{l}27 \\
\text { female }\end{array}$ & $\begin{array}{l}\text { Chest pain } \\
\text { Syncope } \\
\text { palpitation }\end{array}$ & 3 & 27 & No/No & Subaortic & TAortic & $\begin{array}{l}\text { Septal Free } \\
\text { wall }\end{array}$ & $\begin{array}{l}\text { Septal } \\
\text { resection Free } \\
\text { wall resection }\end{array}$ & $\begin{array}{l}\text { Radiofrequency } \\
\text { ablation }\end{array}$ & NYHA 1 \\
\hline 5 & $\begin{array}{l}50 \\
\text { male }\end{array}$ & $\begin{array}{l}\text { Chest pain } \\
\text { Syncope } \\
\text { Palpitation }\end{array}$ & 3 & 46 & No/No & Subaortic & TAortic & Septal & NA & & NYHA 2 \\
\hline 6 & $\begin{array}{l}14 \\
\text { male }\end{array}$ & Chest pain & 2 & 11 & Yes/No & $\begin{array}{l}\text { Subaortic } \\
\text { APM }\end{array}$ & $\begin{array}{l}\text { TAortic } \\
\text { APM } \\
\text { resection }\end{array}$ & Septal & NA & & NYHA 1 \\
\hline 7 & $\begin{array}{l}15 \\
\text { female }\end{array}$ & Chest pain & 3 & 14 & No/No & Subaortic & TAortic & $\begin{array}{l}\text { Septal } \\
\text { Infundibular }\end{array}$ & $\begin{array}{l}\text { Septal } \\
\text { resection } \\
\text { Infundibular } \\
\text { resection }\end{array}$ & & NYHA 1 \\
\hline 8 & $\begin{array}{l}7 \\
\text { male }\end{array}$ & $\begin{array}{l}\text { Chest pain } \\
\text { Dyspnea } \\
\text { syncope }\end{array}$ & 3 & 5 & No/No & $\begin{array}{l}\text { Subaortic } \\
\text { APM }\end{array}$ & $\begin{array}{l}\text { TAortic } \\
\text { APM } \\
\text { resection }\end{array}$ & $\begin{array}{l}\text { Septal Free } \\
\text { wall }\end{array}$ & $\begin{array}{l}\text { Septal } \\
\text { resection Free } \\
\text { wall resection }\end{array}$ & & \\
\hline 9 & $\begin{array}{l}15 \\
\text { male }\end{array}$ & $\begin{array}{l}\text { Chest pain } \\
\text { syncope }\end{array}$ & 2 & 12 & No/No & Subaortic & TAortic & $\begin{array}{l}\text { Septal } \\
\text { Infundibular }\end{array}$ & $\begin{array}{l}\text { Septal } \\
\text { resection } \\
\text { Infundibular } \\
\text { resection }\end{array}$ & CABG & NYHA 1 \\
\hline 10 & $\begin{array}{l}50 \\
\text { female }\end{array}$ & $\begin{array}{l}\text { Chest pain } \\
\text { palpitation }\end{array}$ & 3 & 45 & No/No & Subaortic & TAortic & Septal & $\begin{array}{l}\text { Septal } \\
\text { resection }\end{array}$ & & NYHA 2 \\
\hline 11 & $\begin{array}{l}32 \\
\text { female }\end{array}$ & $\begin{array}{l}\text { Chest pain } \\
\text { Palpitation } \\
\text { syncope }\end{array}$ & 4 & 30 & No/Yes & Subaortic & TAortic & $\begin{array}{l}\text { Septal Free } \\
\text { wall }\end{array}$ & $\begin{array}{l}\text { Septal } \\
\text { resection Free } \\
\text { wall resection }\end{array}$ & & NYHA 2 \\
\hline 12 & $\begin{array}{l}27 \\
\text { female }\end{array}$ & $\begin{array}{l}\text { Chest pain } \\
\text { Dyspnea } \\
\text { Palpitation }\end{array}$ & 3 & 25 & No/No & $\begin{array}{l}\text { Subaortic } \\
\text { APM }\end{array}$ & $\begin{array}{l}\text { TAortic } \\
\text { APM } \\
\text { resection }\end{array}$ & $\begin{array}{l}\text { Septal Free } \\
\text { wall }\end{array}$ & $\begin{array}{l}\text { Septal } \\
\text { resection Free } \\
\text { wall resection }\end{array}$ & $\begin{array}{l}\text { Tricuspid valve } \\
\text { replacement }\end{array}$ & NYHA 2 \\
\hline 13 & $\begin{array}{l}37 \\
\text { male }\end{array}$ & $\begin{array}{l}\text { Chest pain } \\
\text { Dyspnea } \\
\text { syncope }\end{array}$ & 3 & 7 & Yes/No & $\begin{array}{l}\text { Subaortic } \\
\text { APM } \\
\text { MidV }\end{array}$ & $\begin{array}{l}\text { TAortic } \\
\text { APM } \\
\text { resection }\end{array}$ & $\begin{array}{l}\text { Septal Free } \\
\text { wall APM }\end{array}$ & $\begin{array}{l}\text { Septal } \\
\text { resection Free } \\
\text { wall resection } \\
\text { APM } \\
\text { resection }\end{array}$ & & NYHA 1 \\
\hline
\end{tabular}

\section{Echocardiography}

The mean interventricular septal thicknesses in the group with SRVH and that without SRVH was $27.29 \pm 7.95$ and $24.33 \pm 5.85$ $\mathrm{mm}$, respectively $(\mathrm{p}=0.027)$, and the mean LVOT gradient in the groups was $80.83 \pm 24.41$ and $42.30 \pm 5.70 \mathrm{~mm} \mathrm{Hg}$, respectively $(p<0.001)$. Moreover, 13 patients $(36.11 \%)$ with SRVH exhibited RVOTO at rest, with a peak pressure gradient of $62 \mathrm{~mm} \mathrm{Hg}$. There were no significant differences between the two groups in the 

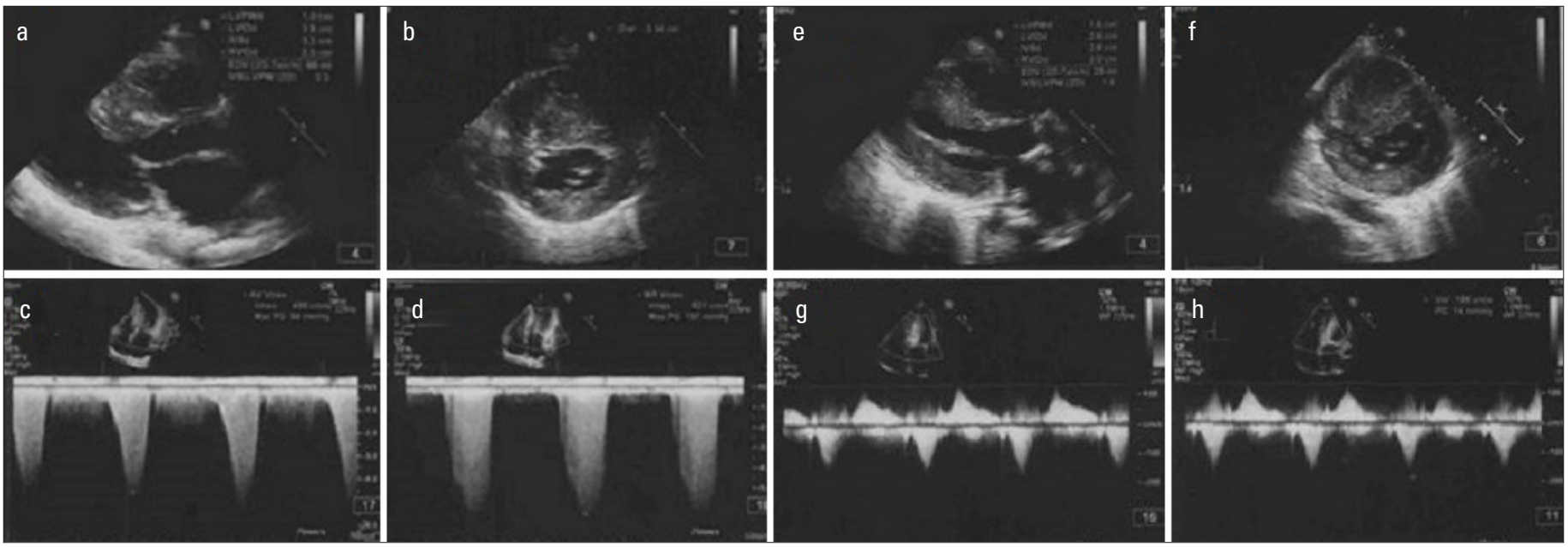

Figure 2. Echocardiographic images of a woman aged 33 years with HCM, SRVH, and BVOTO who underwent biventricular resection. (a) Preoperative parasternal left ventricular long-axis view. (b) Preoperative parasternal left ventricular short-axis view. (c) Preoperative Doppler view of the right ventricular outflow tract. (d) Preoperative Doppler view of the left ventricular outflow tract. (e) Postoperative parasternal left ventricular long-axis view. (f) Postoperative parasternal left ventricular short-axis view. $(\mathrm{g})$ Postoperative Doppler view of the right ventricular outflow tract. (h) Postoperative Doppler view of the left ventricular outflow tract BVOTO - biventricular outflow tract obstruction; HCM - hypertrophic cardiomyopathy; SRVH - severe right ventricular hypertrophy

left atrial and LV end-diastolic dimension, LV posterior wall thickness, or LV ejection fraction.

\section{CMR imaging}

Diffuse RV hypertrophy was commonly observed in patients in the group with SRVH, with a maximum RV wall thickness of $10.4 \pm 2.9 \mathrm{~mm}$. Narrowing of the biventricular outflow tract because of protrusion of the ventricular septum and RV free wall hypertrophy were clearly observed in 13 patients with BVOTO. The maximal LV wall thickness was significantly greater in the group with SRVH than in the group without SRVH $(29.67 \pm 7.97$ vs. $26.68 \pm 6.02 \mathrm{~mm}$, respectively; $p=0.018$ ). Furthermore, the prevalence of LGE was higher in the group with SRVH than in the group without SRVH $[\mathrm{n}=35(97.22 \%)$ vs. $\mathrm{n}=70(54.69 \%)$, respectively; $p=0.013$ ]. A total of 10 patients with SRVH exhibited LGE in the hypertrophic RV wall.

\section{Follow-up}

All the 164 patients with HCM were followed up for a median of 48 months (range: 6-66 months). Follow-up data were obtained either through detailed interviews or by examining medical records. A total of 30 patients in the group with SRVH underwent surgical treatment. Specifically, 17 patients with LVOTO and 2 patients with BVOTO underwent the modified enlarged Morrow procedure [a 3-5 $\mathrm{mm}$ hypertrophic region of the subaortic valve was resected to relieve LVOTO (8)] in the left side of the heart, whereas 11 patients with BVOTO underwent biventricular resection (modified enlarged Morrow procedure in the left side of the heart and RV outflow dissection in the right side of the heart). We summarized the clinical data, anatomical features, surgical procedures, and outcomes of the 13 patients with BVOTO (Table 3). In addition, a boy aged 14 years with end-stage HCM with NYHA functional class IV underwent heart transplantation, and a man aged 52 years underwent percutaneous transluminal septal myocardial ablation. The remaining four patients received medication therapy (mainly $\beta$-blockers).
After surgical myectomy, most patients exhibited significant improvements in their NYHA functional class, with a substantial reduction in the maximal septal thickness, left atrial diameter, and residual LVOT and RVOT gradients (in patients with BVOTO). Table 4 summarizes the preoperative and postoperative echocardiographic parameters in the group with SRVH. Figure 2 shows the preoperative and postoperative echocardiographic data of a woman aged 33 years with HCM, SRVH, and BVOTO. Figure 3 shows the preoperative and postoperative CMR imaging data of a boy aged 16 years with HCM in the group with SRVH.

Although the clinical symptoms and echocardiographic parameters in the group with SRVH clearly improved after surgical treatment, the clinical prognosis was not so optimistic. Six patients with SRVH reached the primary clinical endpoints (SCD in four patients, heart failure-related death in one patient, and heart transplantation in one patient), whereas only two SCDs occurred in the group without SRVH.

Kaplan-Meier estimates demonstrated that the endpointfree survival rate was lower in the group with SRVH than in the group without SRVH (log-rank, $\mathrm{p}<0.001$ ) (Fig. 4a). Among all patients with SRVH, no significant differences in age, sex, baseline NYHA function, interventricular septal thickness, LVOT gradient, or BVOTO were identified between those who reached and did not reach the primary endpoint (Table 5 and Fig. $4 b$ ).

\section{Discussion}

It is now widely accepted that HCM is a disease involving both cardiac ventricles rather than being morphologically limited to the left ventricle. The incidence of RV hypertrophy in patients with $\mathrm{HCM}$ is $30 \%-53 \%$ as shown by CMR imaging and echocardiography studies $(6,7,9,11)$, whereas SRVH is relatively uncommon (prevalence of $1.3 \%$ ) (12). In our study, among the 1,316 patients with HCM who underwent LGE CMR imaging 


\begin{tabular}{|c|c|c|c|}
\hline Variable & Preoperative & $\begin{array}{l}\text { Postoperative } \\
\text { (6 months after) }\end{array}$ & $\boldsymbol{P}$ \\
\hline $\mathrm{LA}(\mathrm{mm})$ & $42.12 \pm 7.31$ & $38.82 \pm 7.58$ & 0.011 \\
\hline LVEDD (mm) & $40.45 \pm 8.65$ & $42.18 \pm 7.54$ & 0.084 \\
\hline IVST (mm) & $27.29 \pm 7.95$ & $17.96 \pm 6.68$ & $<0.001$ \\
\hline Dilated RA (\%) & $2(7.4 \%)$ & $2(7.4 \%)$ & 1.000 \\
\hline LVOT gradient (mm Hg) & $80.83 \pm 24.41$ & $8.88 \pm 9.044$ & 0.009 \\
\hline $\begin{array}{l}\text { RVOT gradient }(\mathrm{mm} \mathrm{Hg}) \\
(\mathrm{n}=13)\end{array}$ & $44.86 \pm 25.5$ & $16 \pm 19.72$ & 0.022 \\
\hline NYHA III/IV & $24(67.2 \%)$ & $11(30.55 \%)$ & 0.025 \\
\hline \multicolumn{4}{|c|}{$\begin{array}{l}\text { Data are presented as n (\%) or mean } \pm \text { standard deviation. } \\
\text { IVST - interventricular septal thickness; NYHA - New York Heart Association; LA - left } \\
\text { atrium; LVEDD - left ventricular end-diastolic dimension; LVOT - left ventricular outflow } \\
\text { tract; RA - right atrium; RVOT - right ventricular outflow tract; SRVH - severe right } \\
\text { ventricular hypertrophy }\end{array}$} \\
\hline
\end{tabular}

\begin{tabular}{|c|c|c|c|}
\hline Variables & $\begin{array}{c}\text { Patients } \\
\text { who reached } \\
\text { endpoint }(n=6)\end{array}$ & $\begin{array}{l}\text { Patients who not } \\
\text { reached endpoint } \\
\qquad(n=30)\end{array}$ & $\boldsymbol{P}$ \\
\hline Age (years) & $19.00 \pm 7.67$ & $29.3 \pm 15.70$ & 0.129 \\
\hline Gender (male) & $22.67 \pm 8.937$ & $34.86 \pm 17.81$ & 0.115 \\
\hline Baseline NYHA III/IV & $3(50 \%)$ & $21(70 \%)$ & 0.378 \\
\hline IVST (mm) & $28.60 \pm 8.56$ & $27.00 \pm 7.98$ & 0.691 \\
\hline LVOT gradient $(\mathrm{mm} \mathrm{Hg})$ & $77.25 \pm 19.17$ & $81.38 \pm 25.39$ & 0.759 \\
\hline BVOTO & $1(16.7 \%)$ & $12(40 \%)$ & 0.385 \\
\hline
\end{tabular}

Data are presented as $\mathrm{n}(\%)$ or mean \pm standard deviation.

BVOTO - biventricular outflow tract obstruction; IVST - interventricular septal thickness; LVOT - left ventricular outflow tract; NYHA - New York Heart Association; SRVH - severe right ventricular hypertrophy

from 2013 to 2017, 36 patients with concurrent HCM and SRVH were identified (prevalence of $2.7 \%$ ).

Previous studies have identified a significant correlation between the maximum RV and LV wall thickness (7). Consistent with previous studies, patients with SRVH in this study had a significantly greater maximal LV wall thickness than patients without. Moreover, patients with SRVH in this study demonstrated a significantly greater LVOT gradient than patients without, which suggests that SRVH is correlated with more severe obstructive HCM phenotypes.

Previous studies have demonstrated that RV hypertrophy in patients with HCM is associated with an increased incidence of severe dyspnea and that progressive heart failure is more frequent among patients with SRVH $(5,9,13)$. Our findings are comparable with those of these studies. Increased RV stiffness and reduced RV compliance due to RV hypertrophy are pathogenetic mechanisms proposed to explain the severity of symptoms in patients with RV hypertrophy (5). Furthermore, in most cases, symptoms are more severe if RV hypertrophy is combined with RV obstruction (14). In contrast to the dynamic lesions that occur in LVOTO associ-
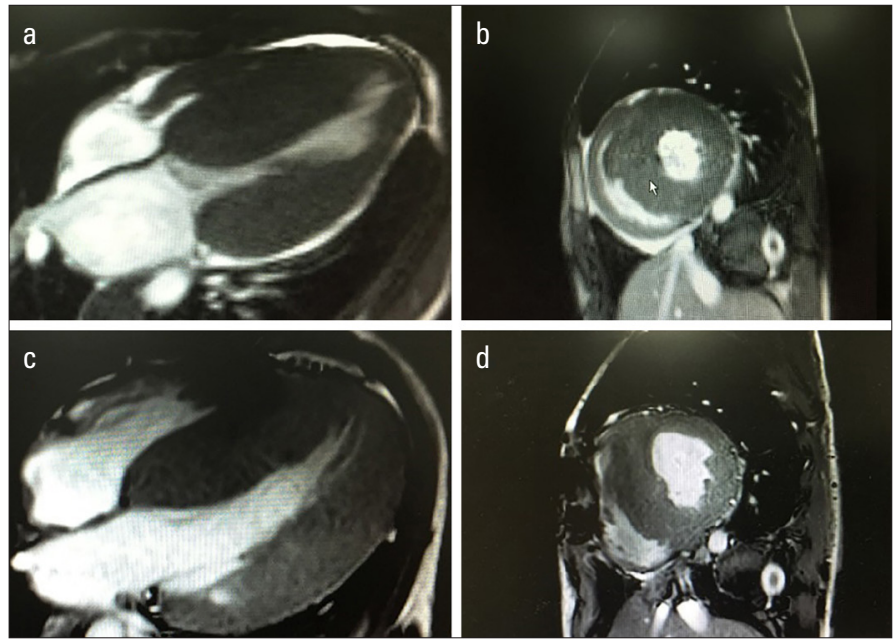

Figure 3. Preoperative and postoperative CMR images of a boy aged 16 years with HCM and SRVH. (a) Preoperative long-axis CMR image demonstrating massive septal hypertrophy and thickening of the ventricular septum bulging into the LVOT and RVOT, resulting in biventricular obstruction. (b) Postoperative short-axis CMR image. (c) Postoperative long-axis CMR image demonstrating a significantly thinner ventricular septum and extensive expansion of the LVOT and RVOT. (d) Postoperative short-axis CMR image

CMR - cardiac magnetic resonance; HCM - hypertrophic cardiomyopathy; LVOT - left ventricular outflow tract; RV - right ventricular, RVOT - right ventricular outflow tract; SRVH - severe right ventricular hypertrophy

ated with systolic anterior motion, obstruction in the right ventricle is caused by a static and fixed impediment to RV outflow, including projection of a hypertrophied RV infundibulum or septum into the RV cavity, free-wall hypertrophy, and abnormal papillary muscles $(15,16)$. RVOTO is often accompanied by LVOTO, which causes BVOTO. BVOTO can cause lethal hemodynamic changes in patients with HCM. These patients also present with a more advanced NYHA functional class (III/IV) that requires surgical intervention compared with patients with LVOTO only $(17,18)$. The clinical characteristics of patients with BVOTO in our cohort were similar to those reported by Zhai et al. (17) and Quintana et al. (18).

Surgical correction of ventricular outflow obstruction in patients with HCM is usually based on transaortic access to the left side of the interventricular septum followed by resection of the subaortic muscle, which is commonly known as the Morrow procedure (19). However, there is no standard for surgical correction of HCM in patients with biventricular obstruction. Early studies showed that biventricular resection in patients with HCM is ineffective and associated with a high risk of death (15, $20,21)$. Borisov (22) presented his experience in a cohort of seven patients with simultaneous mid-LVOTO and RVOTO using a single limited RV longitudinal incision. Quintana et al. (18) recently reported that biventricular resection could relieve both LVOTO and RVOTO with a low mortality rate and good long-term outcomes. In our study, biventricular resection was performed in 11 of 13 patients with BVOTO, whereas the remaining two patients with mild RVOTO (RVOT gradient $<50 \mathrm{~mm} \mathrm{Hg}$ ) underwent $\mathrm{LV}$ resection alone. Among the eight patients who underwent biventricular resection in this study, one patient presented with SCD three years after surgery, and the remaining seven patients showed a clear improvement in clinical symptoms. 

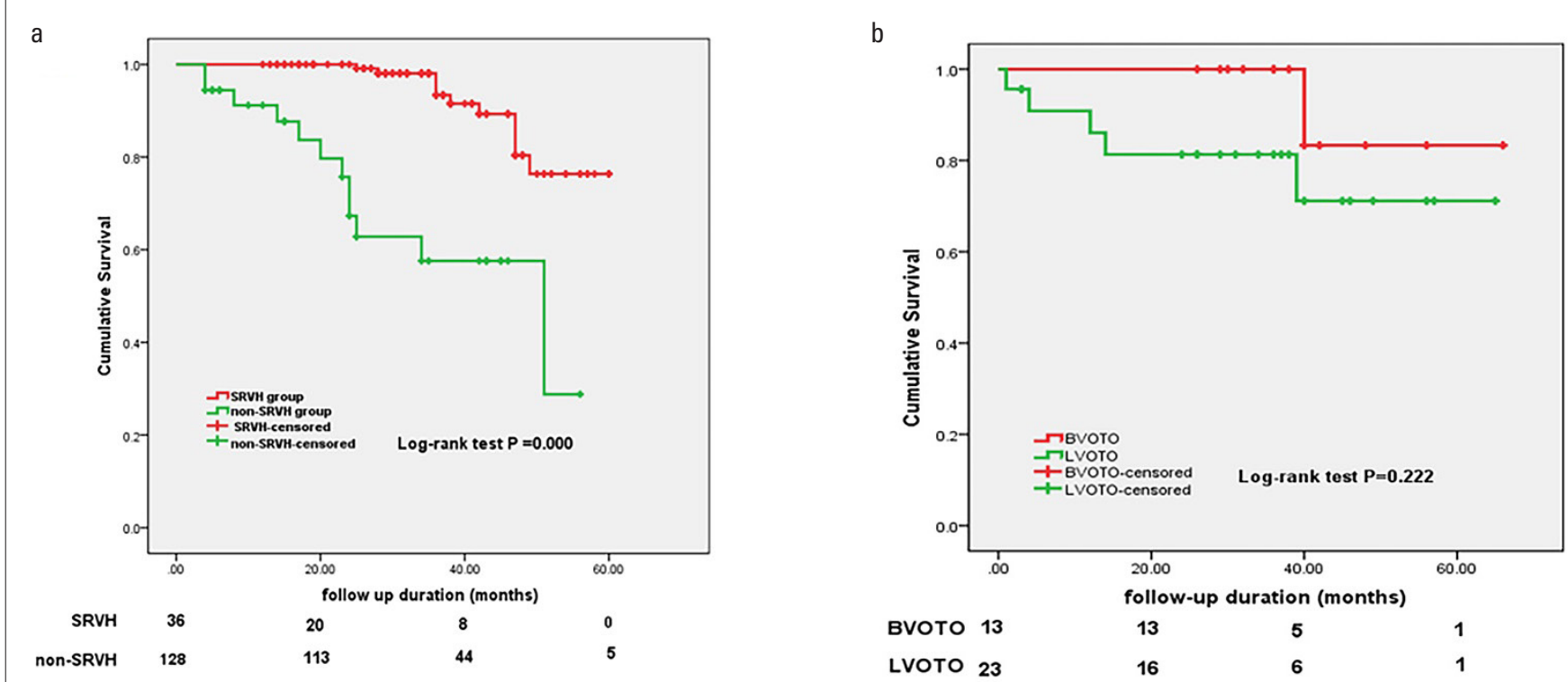

Figure 4. Kaplan-Meier curve. (a) Endpoint-free survival rate in the patients with and without SRVH $(P<0.01)$. (b) Endpoint-free survival rate of patients with BVOTO and LVOTO in the group with SRVH $(P=0.222)$

BVOTO - biventricular outflow tract obstruction; LVOTO - left ventricular outflow tract obstruction; RV - right ventricular; SRVH - severe right ventricular hypertrophy

Patients with SRVH face a high risk of SCD even after successful surgery. In our study, 4 of 36 patients $(11.1 \%)$ with SRVH developed SCD during a median follow-up period of 48 months with an annual SCD rate of $2.7 \%$, which is significantly higher than the annual SCD rate of $<1 \%$ observed in the general population with $\operatorname{HCM}(8,23,24)$. The high risk of $\operatorname{SCD}$ among patients with sudden RV hypertrophy in our study may be attributed to the following: (1) younger patients were included in the group with SRVH, (2) there was a higher incidence of ventricular tachycardia in the group with SRVH, and (3) an increased percentage of myocardial fibrosis was determined using LGE. Although RV involvement is not currently included in the SCD risk score, previous studies have shown that RV wall thickness is independently correlated with malignant ventricular arrhythmia (25).

\section{Study limitations}

Our study has several limitations that should be highlighted. Because our hospital is a tertiary medical institution specializing in cardiovascular disease, most patients in our cohort had severe symptoms and significant ventricular obstruction; this might have led to selection bias. Therefore, our study results may differ from the natural world of HCM with SRVH. In addition, our study adopted a retrospective design with a small sample size and a short follow-up period. Studies with a larger sample size and a longer follow-up period are required to obtain a more accurate understanding of this phenotype.

\section{Conclusions}

In this study, we demonstrated that SRVH is an uncommon phenotype in HCM. Patients with SRVH tend to present with severe symptoms that require complex surgical procedures. These patients face a poor clinical prognosis even after successful surgical correction. Evaluation of the right side of the heart in patients with $\mathrm{HCM}$ should receive more attention from clinicians.

Acknowledgments: The authors thank all the subjects for participating in this study.

Institutional and financial support: This study was funded by Clinical Transformation and Transformation Fund of Chinese Academy of Medical Sciences (2019XK320058), the National Natural Science Foundation of China (No. 81974042), and the Graduate Innovation Fund of Peking Union Medical College (2019-1002-35).

Conflict of interest: None declared.

Peer-review: Externally peer-reviewed.

Author contributions: Concept - X.D.; Design - X.D., X.M.; Supervision - Y.L., X.Z.; Fundings - Y.L., X.Z.; Materials - X.D., L.Z.; Data collection \&/or processing - D.Z., Y.Q., X.M., L.Z., X.Z.; Analysis \&/or interpretation - X.D., D.Z.; Literature search - X.D., Y.Q.; Writing - X.D.; Critical review - Y.L., X.Z.

\section{References}

1. Marian AJ, Braunwald E. Hypertrophic Cardiomyopathy: Genetics, Pathogenesis, Clinical Manifestations, Diagnosis, and Therapy. Circ Res 2017; 121: 749-70. [Crossref]

2. Elliott $P$, McKenna $W$. The science of uncertainty and the art of probability: syncope and its consequences in hypertrophic cardiomyopathy. Circulation 2009; 119: 1697-9. [Crossref]

3. Authors/Task Force members, Elliott PM, Anastasakis A, Borger MA, Borggrefe M, Cecchi F, et al. 2014 ESC Guidelines on diagnosis 
and management of hypertrophic cardiomyopathy: the Task Force for the Diagnosis and Management of Hypertrophic Cardiomyopathy of the European Society of Cardiology (ESC). Eur Heart J 2014; 35: 2733-79. [Crossref]

4. Keramida K, Lazaros G, Nihoyannopoulos P. Right ventricular involvement in hypertrophic cardiomyopathy: Patterns and implications. Hellenic J Cardiol 2020; 61: 3-8. [Crossref]

5. Roşca M, Călin A, Beladan CC, Enache R, Mateescu AD, Gurzun $\mathrm{MM}$, et al. Right ventricular remodeling, its correlates, and its clinical impact in hypertrophic cardiomyopathy. J Am Soc Echocardiogr 2015; 28: 1329-38. [Crossref]

6. Nagata Y, Konno T, Fujino N, Hodatsu A, Nomura A, Hayashi K, et al. Right ventricular hypertrophy is associated with cardiovascular events in hypertrophic cardiomyopathy: evidence from study with magnetic resonance imaging. Can J Cardiol 2015; 31: 702-8. [Crossref]

7. Maron MS, Hauser TH, Dubrow E, Horst TA, Kissinger KV, Udelson $\mathrm{JE}$, et al. Right ventricular involvement in hypertrophic cardiomyopathy. Am J Cardiol 2007; 100: 1293-8. [Crossref]

8. McLeod CJ, Ommen SR, Ackerman MJ, Weivoda PL, Shen WK, Dearani JA, et al. Surgical septal myectomy decreases the risk for appropriate implantable cardioverter defibrillator discharge in obstructive hypertrophic cardiomyopathy. Eur Heart J 2007; 28 : 2583-8. [Crossref]

9. McKenna WJ, Kleinebenne A, Nihoyannopoulos P, Foale R. Echocardiographic measurement of right ventricular wall thickness in hypertrophic cardiomyopathy: relation to clinical and prognostic features. J Am Coll Cardiol 1988; 11: 351-8. [Crossref]

10. Maron BJ, Olivotto I, Spirito P, Casey SA, Bellone P, Gohman TE, et al. Epidemiology of hypertrophic cardiomyopathy-related death: revisited in a large non-referral-based patient population. Circulation 2000; 102: 858-64.[Crossref]

11. Mazurkiewicz Ł, Ziółkowska L, Petryka J, Śpiewak M, Małek Ł, Kubik $A$, et al. Biatrial performance in children with hypertrophic cardiomyopathy: CMR study. Eur Radiol 2018; 28: 5148-59. [Crossref]

12. Guo X, Fan C, Tian L, Liu Y, Wang H, Zhao S, et al. The clinical features, outcomes and genetic characteristics of hypertrophic cardiomyopathy patients with severe right ventricular hypertrophy. PLoS One 2017; 12: e0174118. [Crossref]

13. Veselka J, Marel M, Jensen MK. New and existing risk factors in patients with hypertrophic cardiomyopathy. Can J Cardiol 2015; 31 : 699-701. [Crossref]

14. Shimizu M, Kawai H, Yokota Y, Yokoyama M. Echocardiographic assessment of right ventricular obstruction in hypertrophic cardiomyopathy. Circ J 2003; 67: 855-60. [Crossref]
15. Maron BJ, Mclntosh CL, Klues HG, Cannon RO, 3rd, Roberts WC. Morphologic basis for obstruction to right ventricular outflow in hypertrophic cardiomyopathy. Am J Cardiol 1993; 71: 1089-94. [Crossref]

16. Barr PA, Celermajer JM, Bowdler JD, Cartmill TB. Idiopathic hypertrophic obstructive cardiomyopathy causing severe right ventricular outflow tract obstruction in infancy. Br Heart J 1973; 35: 1109-15. [Crossref]

17. Zhai S, Xu H, Fan C, Yang Y, Hang F, Guo X, et al. Mid-term outcomes of biventricular obstruction and left ventricular outflow tract obstruction after surgery correction in child and adolescent patients with hypertrophic cardiomyopathy. PLoS One 2018; 13: e0192218. [Crossref]

18. Quintana E, Johnson JN, Sabate Rotes A, Cetta F, Ommen SR, Schaff HV, et al. Surgery for biventricular obstruction in hypertrophic cardiomyopathy in children and young adults: technique and outcomest. Eur J Cardiothorac Surg 2015; 47: 1006-12. [Crossref]

19. Morrow AG. Hypertrophic subaortic stenosis. Operative methods utilized to relieve left ventricular outflow obstruction. J Thorac Cardiovasc Surg 1978; 76: 423-30. [Crossref]

20. McCully RB, Nishimura RA, Tajik AJ, Schaff HV, Danielson GK. Extent of clinical improvement after surgical treatment of hypertrophic obstructive cardiomyopathy. Circulation 1996; 94: 467-71. [Crossref]

21. Theodoro DA, Danielson GK, Feldt RH, Anderson BJ. Hypertrophic obstructive cardiomyopathy in pediatric patients: results of surgical treatment. J Thorac Cardiovasc Surg 1996; 112: 1589-97. [Crossref]

22. Borisov KV. Surgical correction of hypertrophic obstructive cardiomyopathy in patients with simultaneous obstruction of left ventricular midcavity and right ventricular outflow tract. Eur $\mathrm{J}$ Cardiothorac Surg 2013; 43: 67-72. [Crossref]

23. Elliott PM, Gimeno JR, Thaman R, Shah J, Ward D, Dickie S, et al. Historical trends in reported survival rates in patients with hypertrophic cardiomyopathy. Heart 2006; 92: 785-91. [Crossref]

24. Maron BJ, Rowin EJ, Casey SA, Link MS, Lesser JR, Chan RH, et al. Hypertrophic Cardiomyopathy in Adulthood Associated With Low Cardiovascular Mortality With Contemporary Management Strategies. J Am Coll Cardiol 2015; 65: 1915-28. [Crossref]

25. Maron BJ, Casey SA, Chan RH, Garberich RF, Rowin EJ, Maron MS. Independent Assessment of the European Society of Cardiology Sudden Death Risk Model for Hypertrophic Cardiomyopathy. Am J Cardiol 2015; 116: 757-64. [Crossref] 